DOI https://doi.org/10.18551/rjoas.2016-12.13

\title{
THE MEANINGS OF CORPORATE SOCIAL RESPONSIBILITY TO MINING CORPORATIONS' STAKEHOLDERS IN KONAWE UTARA REGENCY, INDONESIA
}

\author{
Putera Asrip \\ Faculty of Economics and Business, University of Halu Oleo, Indonesia \\ E-mail: asripputera@gmail.com
}

\begin{abstract}
The present study sheds light on various existing meanings stakeholders attached to CSR implemented by nickel mining companies. It becomes the case as those meanings affect the implementation. Accordingly, the purpose of the study is to reveal and interpret corporate social responsibility implementation to its respective stakeholders (public, company and government). The study applies Schultz's qualitative-phenomenological approach. Data is analysed by means of interactive model from Miles and Huberman. It infers that different stakeholders attach different meanings, some of which result on mix and some diffential understandings. Public interprets CSR as its absolute right and thus it is obligatory for any company to provide it, while most companies relate CSR implementation to three factors: the need to heed social concerns, means for company's interests and strategies, and government usually views CSR as public's absolute right and any company must provide, implementation of whivh government plays a role in supervision.
\end{abstract}

\section{KEY WORDS}

Corporate social responsibility, stakeholder, mining companies, phenomenology, regency.

The concept of corporate social responsibility (CSR) is getting increasingly complexed, with different perpectives churn out different definitions. It coincides with continuous refinement by researchers, academicians, companies and other parties concerned about CSR. Debates or convergence in the concept of corporate social responsibility are still in the sight that hinders the way to one-agreed upon definition of CSR.

The analyses ofcorporate social responsibility depart from various approaches starting from charity, philanthropy, legal, moral, strategy to such more popularones as stakeholder dan triple bottom line. Since introduced in 1953 (by Bowen), the concept of CSR has been now developing until recent time (Carrol, 1999).

Divergent responses to CSR effect on development lead to pessimistic and optimistic schims. The former holds the conviction that CSR does not serve as a panacea to any social problems. It is based on two grounds. First, the nature of any company is profit-driven (Friedman, 1970). CSR is only executed as so far it is considered able to serve company's economic drive. Second, social concerns should appropriately be left to government. Social welfareis one of its major concerns, and it is equipped with resources necessary to make some improvements, of which company lack (Gokulsing, 2011).

According to Sasse dan Trahan (2007) CSR can bring out following consequences: first, CSR can be the drain on its resources, due to the short of adequate experience and method in serving public social needs. Second, given its short-terms nature, its effects are hardly significant to the public. Third, trade-off between social role and profit interest tends to be conflictual rather than complimentary. Social contribution means pressure on company's financial resources.

Levitt (1958) has made an argument that social and welfare issues fall within the domain of government. Concerns over social issues will significantly reduce company's profit (Carrol dan Shabana, 2010).

The optimistic school argue that companies can provide meaningful contributions to social and economic development in neighbourhood where they operate. Several studies 
have provided evidence of CSR'spositive effects (Gokulsing, 2011; Ganecu, et al. , 2012, Sharma dan Kiran, 2012; Jalal, 2011; Apriadi, 2012).

Some studies like Drucker (1984) and Jalal and Darmono (2011) have found that social concerns can turn into business opportunity promising long-terms profitability. Study of Porter dan Linde (1995) has shown that environment can uplift business performance. According to the work of Sharma dan Kiran (2012), company will benefit from social concerns. Gunawan dan Utami' study (2008) has shown that CSR can add company's value.

Companies conducting CSR have better social and economic outlook compared to those that are not (Linfei dan Qingliang, 2009). CSR operation can lead to increased working morale, income, and interaction with society (Apriadi, 2012; Mapisangka, 2009). It can be said that CSR program can result in economic and social benefits, referring to improved relation with society.

CSR is considered as being able to bring about ethical and responsible business (Esau dan Malone, 2013; Mapisangka, 2009). Thus it is insufficient for any company to only accommodate the interest of capital owners but also that of other stakeholders (Premovic, et al. , 2012).

Jalal (2011) cites the following benefit that can be drawn from CSR program; easy acces to capital, bigger chances to attract and hold high-skilled employee, heightened product innovation, reduced production cost, increased stock prices, stability in crisis and fast recoveryin post-crisis. According to Kartini (2009) there are two kinds of rewards from CSR program: financial and non financial.

Corporate social responsibility in Indonesia can come handy, particularly as most its population live in poverty, and its most social policies are residual and parsialin nature which is not integrated with taxation system.

According to Jalal (2011) CSR is relatively new in Indonesia, mostly plagued by a highly narrow target on the society around the company, and handouts (philanthropy) as its most form, with no effect on increased economic welfare and autonomy in society. It is largely due to entrenched mainstream view that CSR is not part of management, as it is considered not pertinent to company sustainability. Common practice emphasizes CSR as inherent part of management, and its activity falls within management control accordingly (Freeman, 1984).

Tabel 1 - News Title on CSR Issues of Mining Companies in Konawe Utara Regency (South-East Sulawesi, 2013-2016)

\begin{tabular}{|c|c|c|}
\hline Headline & Media & Edition \\
\hline $\begin{array}{l}339 \text { perusahaan di Sultra tidak laksanakan CSR (339 enterprises } \\
\text { in south-eastern Sulawesi did not implement CSR programs) }\end{array}$ & antarasultra.com & August $24^{\text {th }}, 2016$ \\
\hline $\begin{array}{l}\text { Sebanyak } 339 \text { perusahaan di Sultra tidak laksanakan CSR (As } \\
\text { many as } 339 \text { enterprises in south-eastern Sulawesi did not } \\
\text { implement any CSR programs) }\end{array}$ & ekspolorasi. id & August $24^{\text {th }}, 2016$ \\
\hline $\begin{array}{l}\text { Mayoritas perusahaan tambang di Sultra belum jalankan program } \\
\text { CSR (Majority of mining companies in Sulawesi Tenggara } \\
\text { Province not showing any signs to CSR programs) }\end{array}$ & energywold.co.id & August $24^{\text {th }}, 2016$ \\
\hline $\begin{array}{l}\text { Alasan tak berproduksi, } 6 \text { bulan PT Timah tak bayar CSR (Stop } \\
\text { producing, PT Timah did not commit CSR programs for } 6 \text { months) }\end{array}$ & zonasultra.com & Feb. $20^{\text {th }}, 2016$ \\
\hline $\begin{array}{l}\text { Suka obral CSR "omdo" PT Stargate Pasific Resources dirusak } \\
\text { warga (Bluffing about CSR programs, people broke the office of } \\
\text { PT Stargate Pacific Resources) }\end{array}$ & lensaindonesia.com & July $11^{\text {th }}, 2013$ \\
\hline $\begin{array}{l}\text { Masyarakat Langgikima Belum Terima Dana CSR Perusahaan } \\
\text { Tambang (People of Langgikimia have not received any CSR } \\
\text { fund from mining companies) }\end{array}$ & energitoday & September $30^{\text {th }}, 2013$ \\
\hline $\begin{array}{l}\text { Warga Langgikima (Konut) Tak Tersentu CSR (People of } \\
\text { Langgikimia (Konut) are far away from CSR funds) }\end{array}$ & sultra online & September $28^{\text {th }}, 2013$ \\
\hline $\begin{array}{l}\text { Warga Lingkar Tambang Konut, Tuntut Biaya Pengobatan Ispa } \\
\text { (People around Konut Mining demanded costs for lungs disease) }\end{array}$ & kendarinews.com & September $30^{\text {th }}, 2013$ \\
\hline $\begin{array}{l}\text { Konut: Program Comdev Lingkar Tambang Dipertanyakan (Konut: } \\
\text { The Comdev Program is questioned) }\end{array}$ & kendarinews.com & September 29, 2013 \\
\hline
\end{tabular}


Partial CSR can lead to common issues such as short-terms results, good image orientation (Jalal, 2011), disillusion on the part of society and government (Putera et al, 2015), and unsustainability of the program (Elkington (1997), Wibisono (2007).

Nickel-mining companies in Konawe Utara Regency have implemented CSR in various forms (Putera et al, 2015), but news covering the results and effects presenting otherwise (table 1). It is assumed that this is mainly caused by partial concepts of CSR held by company, society and government. Different interpretations lead to conflictual goals.

The study intends to reveal what CSR means to society, government and companies. The study explores the internal views of stakeholders (public, government and companies) as to CSR program.

\section{METHODS OF RESEARCH}

Study Approach. Based on the focus and purpose of the study, it applies qualitativephenomenology as its approach. Phenomenology intends to reveal the truth behind the phenomenon. Hadiwiyono (1980) and Waters (1994, in Basrowi and Sukidin, 2002) hold that to arrive at the basic truth, one should get through physical reality. Adian (2010) suggests that phenomenology is a holistic approach that captures reality in a natural way as contrasted to partial.

Phenomenologyhas many schools of thought including among others: Schultz, Berger, Heidegger, Sartre, Ponty, and others. Phenomenology is based on flexible way of thinking relying on inductive analysis putting research data not as an instrument to prove arguments rather as foundation to arrive at understanding (Hasan, 2003).

The present study applies Schultz's phenomenological approach. It is in line with the the purose of the study which intends to understand and interpret the action of individuals reflected in reality. The action is grounded on certain purpose and this purpose is preceded by a certain cause (Fatchan, 2011).

According to Schultz, individual's action is affected by many factors, namely, internal and external. External factors are influences of other people, social-culture, economy, and others. Indivual's behavior is influenced by cause so-called because motive and purpose socalled in order motives. Beside internal and external influences, space and time imposes equally important influences (Fatchan, 2013).

Object of Study. The study was conducted in Konawe Utara Regency, Province of South-East Sulawesi, Indonesia. There were 119 nickel companies in this regency (The Office of Mining and Energy of Konawe Utara Regency, 2014), the largest compared to all other areas. Some had run CSR program such as aid to the sectors of health, education, infrastructure, public facility, and environment (Putera, et al (2015).

Informants. Qualitative study puts information quantity on priority over informants. Thus number of informants is not the main issue so far as information gathered is considered sufficient and valid (Fatchan, 2011). The study, covers three informant categories: public, company and government.

To spot the right informants from three categories, purposivemethod is seen appropriate. By this method,informants are spotted by means of following criteria:

- Public; living around mining site, directly involved in CSR program, having spare time to share information, willing to share information in line with their experiences.

- Company; has or in the project of CSR, willing to provide objective information.

- Government; chief of Office of Mining and Energy, former chief, Office' staff, head of municipality, village head, secretary handling issues related to the company, having time to share information.

The informants in this study were 20 people including chief of Office of Mining and Energy, former chief, Office' staff (mining supervisor), company manager, company' staff, municipal head, village head/secretary, and respected figures in society. follows:

Data Gathering Tecnique. Data and information are gathered by several means as 
- Observation, (pre-and post interview). Researcher put himself in the object environment, trying to grasp situation and condition of the object before interview. Postinterview observation is conducted to verify information provided by informants (triangulation).

- In-depth interview is carried out on three patterns; semi- structured, unstructured and unplanned interviews. Duration is arranged according to situation and condition of the informants. The factual interviews run in the range of 30-90 minutes. Semi-structured interview is carried out in the first stage in order to get information related to the focus of study. Unstructured interview is conducted in the second stage in order to confirm dubious information. Unplanned interview is conducted without prior planning, the results of which can support the results of the first and second interviews.

- Documentation that is ; gathering various data from company, government and news, and description of situation involved.

Data Accuracy. To make sure quality of data on hand, test based on several criteria, as set out by Lincoln and Guba (1985, in Fatchan, 2013) can be performed:

- Triangulation, triangulation in this study was performed by several means: First, comparing data gathered from observation to those from interview. The mismatch was tackled by clarification to informants. Second, comparing what is in the informants' mind to others (not informant). Mismatch was tackled by clarification to the concerned informants. Third, comparing the results of interviews to data gathered from mining companies.

- Member check, discussing the results with peers considered as having reliable competence.

Data Analysis. Analysis data was performed by means of interactive technique adopted from Miles and Huberman (1992). Interactive model runs through three analysis stages:

1. Data reduction, covering selecting, simplifying, and categorizing data. It is followed by coding and theme based descriptions of data. By doing so, irrelevant data can be removed.

2. Data presentation, data arrangement in the form of text, matrix, graphic and table.

3. Drawing conclusion.

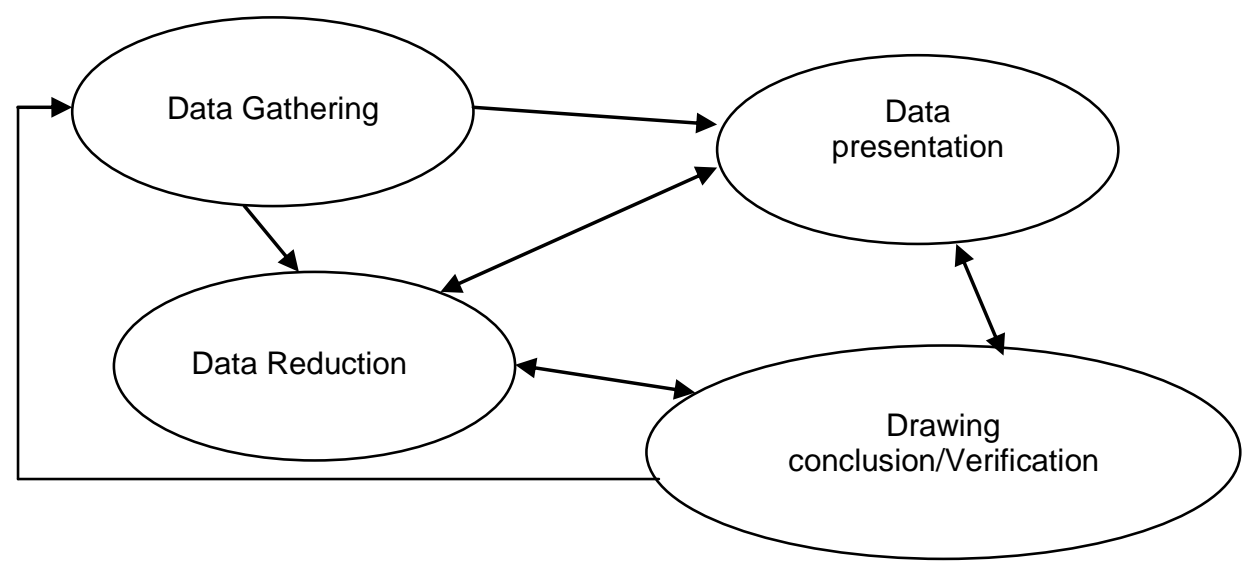

Figure 1 - Interactive Analysis Model (Source: Miles and Huberman, 2009)

Six stages for data analysis:

Stage 1: Data Arrangement. On this stage, researcher puts the results of observation and interview into written text, in the form of meaningful narration.

Stage 2: Sorting or reduction. On this stage researcher sort available data, during which redundant and irrelevant data are removed. The remaining data are thus classified in a such way that several themes emerge.

Stage 3: Identifying Informants' themes. On this stage researcher identifies and analyses the themes of all informants. 
Stage 4: Arranging the themes of all Informants. On this stage, researcher arranges the themes, from which a meaningful description can be made.

Stage 5: Discribing the themes. On this stage, researcher makes a description and explanation the result of which is expected to lead the researcher to new finding.

Stage 6: Syinthesizing or comparing the themes. On this stage, researcher make compartison between what found from themes to applied theories and concepts necessary to support or disproval them. It might lead to new finding in the form of proposition.

\section{RESULTS AND DISCUSSION}

To understand deeply the meaning ofcorporate social responsibility (CSR) to public, company and government, the study synthesizes themes from informants. The signification is directed to find because of motive and in order to motive behind corporate social responsibility (CSR) program.

The Meaning of CSR to Local Public. Public mostly interprets Corporate social responsibility (CSR) as right to be fulfilled by company to offset its acceptance of company operation in neighbourhood. Some informants state that as company has enjoyed much profit from its operation on public's land it that should compensate it in the form of aid to social concerns.

Much earlier, local people did not realize that there should be social contribution from company. It was mainly due to limited information access and low education. The economic activities of companies and local people studying in other areas enabled for wider acces of information. This in turn help develop the awareness of CSR.

This causes many people rely on company to fulfill so many needs or build so many infrastructures on the villages nearby. They for example asked that electric engines handout should be accompanied with gasoline and maintenance in case of malfunction. They also proposed clean water and asphalting should be included in CSR program.

Capability and willingness to meet these proposals determine their status as a good company or othermine in the eyes of public. The best one among others is Stargate Pasific Resources (SPR) corporation for its record as the most active in CSR program, eventhough notoriously the biggest contributor on environment damage. Part of CSR programs are driven by social pressure. The pressure is shown by means of demonstration as public think that the delays of CSR program has been too long.

Referring to Elkington (1997) and Wibisono (2007), nickel companies can fall in red category (Wibisono) and grasshopper (Elkington). Companies start to perform CSR program when they get pressure from stakeholders, and they tend to skip the program when pressue is non-existent.

Proposition 1: CSR is public's absolute right as compensation to company's operation in public's land.

Meaning CSR to Companies. Incorporation Act. No 40 of 2007 requires companies to implement CSRR program, especially those with inclination to inflict environment damage, like mining. Mining companies have taken this requirement in a good term, and implement the program in education, religion, health, and infrastructures.

Common motives behind CSR program for companies are to fulfill the above requirement, effort to build infrastructure for common interest and corporate strategy. Companies' informants state that fulfilling the legal requirement is essential to make company have a good image, abiding by positive law and regional regulation.

Incorporation Act. No. 40 of 2007 makes clear a requirement for companies to perform CSR program. In following up, Government of Konawe Utara Regency releases regional regulation as to CSR, that is Regional Regulation No. 1 of 2014 on Third Party's Contribution (SPK). SPK is mining companies' contribution to public of Konawe Utara Regency through regency government.

Corporate budgeting planning (RKAB) should include past and future CSR program planningto be approved by Regional Office of Mining and Energy. Ignoring this point can 
make the Office turn down RKAB and send back to the concerned company to make further correction.

CSR program should not obligatory in nature, following as stated in regulation (Linfei dan Qingliang, (2009). Kotler and Lee (2005) suggest that companies should directCSR program to support corporate objectives. It should contribute to company's value chain, strategy and operation (Porter and Kramer, (2006); Werther and Chandler, (2006) in Bhattacharyya, et al. (2008).

Common interest can be materialized through infrastrustructure building that serves the interest of public and that of company. One example is repairing highway and bridge that serve as a vital means for both.

Company can apply CSR program as its strategy. This program can be directed to make local people accept and support the company operation that can have negative impact to environment. The support from local people can facilitate approval from local government. In this category CSR takes the form of monthly payments to respected figures in society and government, the numbers of which depend on their respective positions.

Companies' informants state that the payments cover all levels of officials, but incidental in nature rather than periodic. The overwhelming proposals from public for CSR program makes hard for company to plan appropriate CSR budgeting yearly.

Strategical motive gets support from arguments of Sethi, (1979); Carroll, (1979), Wood, (1991); Hopkins, (2003); Bhattacharyya, et al. (2008) that CSR program can foster mutual benefit between company and other stakeholders, especially when the benefit arises"sense of belonging" among local people to company, and accordingly conducive atmosphere for company to run its mining operations.

Informants state that CSR program has provided company many benefits including improved image, support from public and conducive atmosphere for company to conduct mining operation. In similar vein, Kurucz, et al. (2008) in Caroll dan Shabana (2010) argue that CSR program promises several benefits; reduced risks, heightened legitimacy and reputation, a great synergy among stakeholders enabling company to build competitive edge. Suharto (2008) argues that CSR facilitates the way forlincense to operation, brand differentiation, human resource and reduced-risk management.

Proposition 2: Motivations behind CSR are legal requirement, common interest and corporate strategy, as a means for puclic support and condition for mining operation.

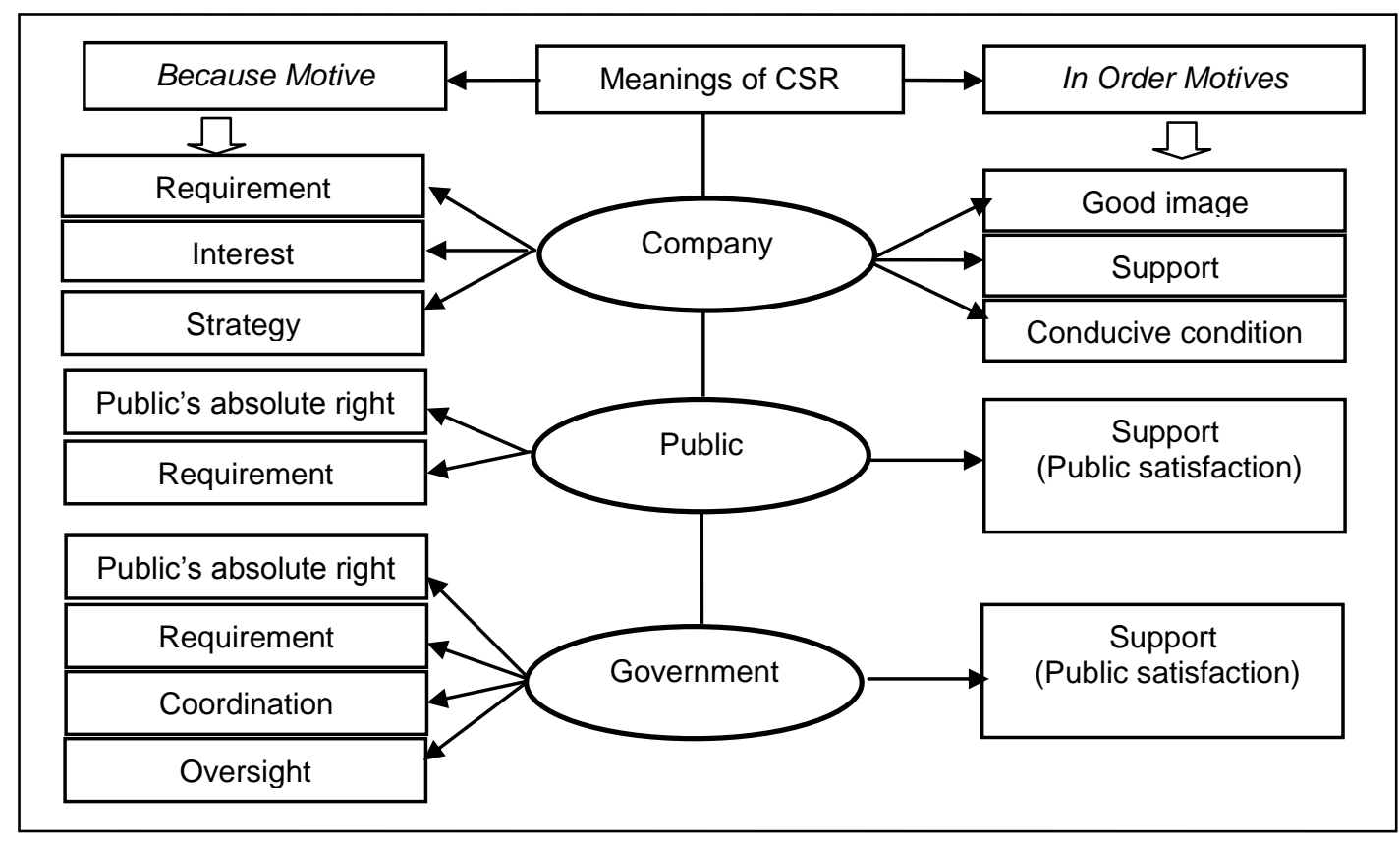

Figure 2 - Meanings of CSR toStakeholders 
Meaning of CSR to Government. The government of Konawe Utara Regency finds it is hard to play as intermediary between company and public. Some obstacles make the function does not run as expected. Supervisory function is not optimally conducted. The office only scan through corporate budgeting planning (RKAB) put forward by company without overseeing its real implementation in the field. The lack of verification between report and result is largely due to the absence of human resource with CSR supervision relatedskill.

Company generally tends to directly coordinate with public without involving government. This lack of coordination makes synergy between company and government impossible, leading to overlapping contributions. Not surprisingly, some villages receive contributions much larger or more ofthen than the others.

Regional Regulation No. 1 of 2014 on Third Party's Contribution (SPK) is intended to make contributions spread equally across Konawe Utara Regency, covering the areas without mining sites. Some informants state that corporate monetary contribution is shared according to $60: 40$ formula. The sixty percents go to area with mining sites, and the rest to without.

Proposition 3: For CSR to be more successful, government coordination and intensive oversight are essential.

\section{CONCLUSION}

Meanings of CSR tostakeholders are partly different and partly the same. Public interprets CSR as its absoluteright to be provided by company, while company consideres CSR as a means to fulfill legal requirement, and to serve its own interest and corporate strategy. A government state that CSR is public's absolute right, and government coordination and oversight are essential to make it to make it successful.

\section{REFERENCES}

1. Adian, D. G. (2010). Pengantar Fenomenologi. Koekesan. Depok

2. Apriadi, D. W. (2012). Implementasi Program Corporate Social Responsibility PT. Wilmar Nabati Indonesia Gresik di Desa Karangkering Kecamatan Kebomas Kabupaten Gresik. BioKultur, Vol. I/No. 2/Juli- Desember 2112, hal. 149

3. Basrowi \& Sukidin. (2002). Metode Penelitian Kualitatif Persepektif Mikro. Cetakan Pertama. Insan Cendekia. Surabaya

4. Bhattacharyya, S. S. , Arunditya, S. , Pratap, A. A. , \& Abha, C. (2008). A Toolkit For Designing Firm Level Strategic Corporate Social Responsibility (CSR) Initiatives. Vol. 4 No. 3 2008, pp. 265-282, Emerald Group Publishing Limited, ISSN 1747-1117. Social Responsibility Journal.

5. Carroll, A. B. \& Shabana, K. M. (2010). The Business Case For Corporate Social Responsibility: a Review of Concepts, Research and Practice. International Journal of Management Reviews, Vol. 12 No. 1, pp. 85-105.

6. Carroll, A. B. (1979). A Three Dimensional Conceptual Model Of Corporate Performance. The Academy of Management Review, Vol. 4 No. 4, pp. 497-505.

7. Drucker, P. F. (1984). A New Look At Corporate Social Responsibility. McKinsey Quarterly, Vol. 4, Autumn, pp. 17-28.

8. Elkington, J. (1997). Cannibals with Forks: The Triple Bottom Line of $21^{\text {st }}$ Century Business. Capstone. Oxford

9. Esau, G. , \& Malone, M. (2013). CSR In Natural Resources: Rhetoric And Reality. Journal of Global Responsibility. Vol. 4 No. 2, 2013 pp. 168-187

10. Fatchan, A. (2011). Metode Penelitian Kualitatif. Jenggala Pustaka Utama. Surabaya

11. Fatchan, A. (2013). 10 Langkah Penelitian Kualitatif; Pendekatan Konstruksi dan Fenomenologi. Universitas Negeri Malang Press. Malang

12. Freeman, R. E. (1984). Strategic Management: A Stakeholder Approach. Boston, MA: Pitman 
13. Friedman, M. (1970). A Friedman Doctrine: The Social Responsibility of Business Is To Increase its Profits. New York Times Magazine, 13 September.

14. Gunawan, B. dan Utami, S. S. (2008). Peranan Corporate Social Responsibility dalam Nilai Perusahaan. Jurnal Akuntansi dan Keuangan. Vol: 7. No. 2. hal 174-185.

15. Gokulsing, R. D. (2011). CSR Matters in The Development of Mauritius. Social Responsibility Journal. Vol. 7 NO. 2 2011, pp. 218-233, Emerald Group Publishing Limited, ISSN 1747-1117

16. Hasan, T. M. (2003). Metodologi Penelitian Kualitatif; Tinjauan Teoritis dan Praktis. (Cetakan Kedua). LP-Universitas Islam Malang dan Visipress. Surabaya

17. Hopkins, M. (2003). The Planetary Bargain: Corporate Social Responsibility Matters, Earthscan, London.

18. Jalal. (2011). Petaka di Lapangan Tiaka, Kaji Ulang CSR Sektor Migas di Indonesia. . Majalah Bisnis dan CSR. Edisi Maret 2011.

19. Jalal \& Darmono, W. A. (2011). Creating Share Value. Majalah Bisnis dan CSR, September-October 2011.

20. Kartini, D. (2009). Corporate Social Responsibility, Transformasi Konsep Sustainability Management Dan Implementasi di Indonesia. Refika Aditama. Bandung

21. Kotler, P. \& Lee, N. (2005). Corporate Social Responsibility: Doing The Most Good For Your Company and Your Cause. John Wiley \& Sons.

22. Linfei, Z. \& Qingliang, G. (2009). Corporate Social Responsibility in China Apparel Industry. World Academy of Science, Engineering and Technology 272009

23. Mapisangka, A. (2009). Implementasi CSR Terhadap Kesejahteraan Hidup Masyarakat. JESP Vol. 1, No. 1, 2009

24. Miles, M. B. \& Huberman, A. M. (2009). Analisis Data Kualitatif. Translated by T. R. Rohidi, Universitas Indonesia Press. Jakarta

25. Porter, M. E. \& Kramer, M. R. (2006). Strategy \& Society: The Link Between Competitive Advantage And Corporate Social Responsibility. Harvard Business Review, Vol. 84 No. 12 , pp. 56-68.

26. Putera, A. , Surachman, Aisjah, S. , Djumahir. (2015). Why Local Communities Dissatisfaction to CSR Practices of Nickel Mining Companies? Australian Journal of Basic and Applied Sciences (AJBAS) ISSN:1991-8178, ISSN (Print): 9 (11) May 2015, Pages: 966-972. Journal home page: www. ajbasweb.com

27. Premovic, J. , Vujović, S. , Arsić, L. (2012). Corporate Social Responsibility - Imperative Of The Contemporary Business. Innovation Management and Bussiness Performance. Symorg

28. Sasse, C. M. \& Trahan, R. T. (2007). Rethinking The New Corporate Philanthropy, Business Horizons, Vol. 50, Issue 1, pg. 29 - 38, Elsevier Science Inc. , USA

29. Sethi, S. P. (1979). A Conceptual Framework for Environmental Analysis of Social Issues and Evaluation of Business Response Patterns. Academy of Management Review 1979, Vol. 4, No. h 63-74.

30. Suharto, E. (2008). Corporate Social Responsibility: What is and Benefit for Corporate. Paper presented at Corporate Social Responsibility: Strategy, Management and Leadership, Intipesan, Hotel Aryaduta Jakarta.

31. Sharma, A. \& Kiran, R. (2012). Corporate Social Responsibility Initiatives of Major Companies of India with Focus on Health, Education and Environment. African Journal of Basic \& Applied Sciences 4 (3): 95-105, 2012 ISSN 2079-2034

32. Wood, D. (1991). Corporate Social Performance Revisited. Academy of Management Review, Vol. 16 No. 4, pp. 691-718.

33. Wibisono, Y. (2007). Membedah Konsep dan Aplikasi CSR (Corporate Social Responsibility). Gresik: Fascho Publishing. 